\title{
COVID-19 and Recycled Wastewater Irrigation: A Review of Implications
}

\begin{tabular}{|c|c|}
\hline$\underline{\text { M. Moinul H. Oliver }}^{a *}$ & Email: oliver@bsmrau.edu.bd \\
\hline$\underline{\text { Guna A. Hewa }}^{b}$ & Email: guna.hewa@unisa.edu.au \\
\hline$\underline{\text { David Pezzaniti }}^{c}$ & Email: david.pezzaniti@gmail.com \\
\hline M. Ariful Haque $^{d}$ & Email: mdarifuh@ksu.edu \\
\hline$\underline{\text { Shamsul Haque }}^{e}$ & Email: khaque@csu.edu.au \\
\hline M. Manjurul Haque $^{a}$ & Email: haque_bes@bsmrau.edu.bd \\
\hline$\underline{\text { M. Moniruzzaman }}^{a}$ & Email: moniruzzaman@bsmrau.edu.bd \\
\hline$\underline{\text { M. Mostafizar Rahman }}^{a}$ & Email: mostafizar@bsmrau.edu.bd \\
\hline$\underline{\text { Khokan K. Saha }}^{a}$ & Email: ksaha@bsmrau.edu.bd \\
\hline M. Nurul Kadir ${ }^{f}$ & Email: mnkadir.daesau@gmail.com \\
\hline
\end{tabular}

${ }^{a}$ Department of Agricultural Engineering, Bangabandhu Sheikh Mujibur Rahman Agricultural University, Gazipur 1706, Bangladesh

${ }^{b}$ School of Natural and Built Environments, University of South Australia, Mawson Lakes, SA 5095

${ }^{c}$ Independent Water Consultant, Former Senior Research Engineer, Center for Water Management and Reuse (CWMR), University of South Australia, Mawson Lakes, SA 5095

${ }^{d}$ Biological and Agricultural Engineering, Kansas State University, 037 Seaton Hall, Manhattan KS 66506

${ }^{e}$ School of Agricultural and Wine Sciences, Charles Sturt University, Waga Waga, NSW 2678, Australia

${ }^{f}$ Department of Agricultural Engineering, Sher-e-Bangla Agricultural University, Dhaka, Bangladesh

* Corresponding Author; Email: moinul.oliver@gmail.com ; Tel: +8801552407298 


\begin{abstract}
Recycled wastewater is considered as a sustainable source of irrigation water. Despite commendable safety records, viral contamination of agricultural products has occurred the past causing disease outbreaks. This review examines the apprehension that the novel coronavirus (SARS-CoV-2) may also spread through recycled wastewater irrigation (RWI) industry. The novel SARS-CoV-2 is now perceived as an enteric pathogen, and has been found to remain stable in the wastewater for days. Mounting evidences also suggest that viral particles shed by infected individuals through sewage, and greywater is much higher (up to $10 \log _{10}$ ) than the amount typically removed (6-7 $\left.\log _{10}\right)$ through the recycled water disinfection processes. Such gap indicated an increased risk of infection through fecal-oral transmission route. This study also identified greywater irrigation schemes posing a higher risk of transmission of SARSCoV-2. It was recommended that countries putting greywater in the 'low risk' category may rewrite the safety guidelines in post COVID-19 times. This review also suggest that the choice of irrigation method could be critical in protecting the farmers, and the consumers from possible infections during the pandemic. In this regard, irrigation methods (i.e. sprinkler) that generate airborne droplet (leading to aerosols) may be operated with caution when public spaces are in the vicinity. The study also indicated that the developing countries should regulate surface irrigation practice that pump water from polluted rivers during the pandemic.
\end{abstract}

Keywords: Recycled Wastewater, Irrigation, Sprinkler, Coronavirus, SARS-CoV-2 


\section{Introduction}

The use of recycled water has been largely proven safe in the irrigation industry. This is mainly attributed to the disinfection practices (WHO, 2006) followed by the producers and users of recycled water. Despite safety regulations employed in the sector, instances of microbial contamination has also been recorded. Consumption of agricultural products irrigated with wastewater has even caused cross-border outbreaks (Mäde et al., 2013; Sarvikivi et al., 2012; Terio et al., 2015) of infectious diseases. The majority of these outbreaks are from enteric viruses (Bosch et al., 2018) imparting serious burden on the economy and public health. The virus (SARS-CoV-2) behind the most recent outbreak of coronavirus diseases (COVID-19) is also perceived as an enteric pathogen (Gu et al., 2020; Lodder \& Husman, 2020). The pandemic has been declared as "public health emergency of international concern" by the World Health Organization (WHO, 2020). The SARS-CoV-2 virus inflicts respiratory distress in patients and is very similar (Medema et al., 2020) to the severe acute respiratory syndrome (SARS) virus that appeared in 2003 (Manocha et al., 2003; Peiris et al., 2003) and the Middle East respiratory syndrome (MERS) in 2012 (CDC, 2013; Zaki et al., 2012). This similarity (up to 82\%) of SARS-CoV-2 with SARS and MERS is a serious concern for the irrigation industry, particularly for the wastewater users of the world. This is because of the novel virus's likeliness to spread through fecal-oral (Lodder \& Husman, 2020) route of transmission. Although SARSCoV-2 mainly spreads through virus-carrying aerosols during close personal contacts (Gu et al., 2020; F. Q. Wu et al., 2020), there is growing apprehension that sewage wastewaters (Mallapaty, 2020; Wang et al., 2005) could also help spread the virus. SARS-CoV-2 virus has already been traced in sewage waters in the US (F. Q. Wu et al., 2020), Netherlands (Medema et al., 2020) and Sweden (Mallapaty, 2020). Moreover, earlier corona outbreaks (e.g., SARS) was attributed to a faulty sewage line (Cyranoski \& Abbott, 2003) in Hong Kong. Regarding this, later studies explicitly showed evidence of surrogate coronaviruses surviving for days up 
to weeks (L. Casanova et al., 2009) in water and wastewater. This means, even domestic greywater originating from an area with COVID-19 patients might be a potential source of transmission. Such potential fecal-oral or other routes of transmission through wastewater has serious implications on the people working with wastewater management, and reuse in agriculture. Particularly, farmers in the developing world are mostly at risk because, many countries permit unregulated use of wastewater (Mandal, et al., 2011) for irrigation. It is therefore important that SARS-CoV-2 related information are carefully read in the context of irrigation and water management. This manuscript discusses the possible implications of COVID-19 pandemic on the irrigation industry with particular focus on the maneuvers required for ensuring the health and safety of wastewater users in agriculture.

\section{Updating sewage wastewater treatment guidelines}

In order to protect public health safety, any agricultural product irrigated with recycled wastewater must be free from microbial contamination. Viruses, in particular, must be removed/reduced to an acceptable limit in the reusable wastewater. Regarding the scale of removal of viruses, Gerba et al. (2017) argued that traditional 6 to $7 \log _{10}$ reduction (LR) of virus from the wastewater as recommended by WHO (2006) needs further review. This traditional LR criteria set by the WHO was in fact, proposed by the United States Environmental Protection Agency (USEPA) in the early nineties through a series of reviews known as Surface Water Treatment Rules (USEPA, 2016). The aim of such LR during wastewater treatment was to keep "less than one case of microbiologically-caused illness" per year per 10,000 individuals (USEPA, 1990) exposed to recycled wastewater. In order to provide this level of protection, 3-5 LR was proposed considering a specific organism i.e., Giardia cyst. This was also based on the earlier observations that infective virus population in greywater do not usually exceed $6 \log _{10} / \mathrm{L}$ (Asano et al., 2007). Based on this, many countries of the world developed their own criteria. For instance, Queensland Water Supply Regulator 
(2008) in Australia recommends a virus removal credit of $6.5 \log _{10}$ for its best quality recycled sewage water (Class A+). From this perspective, the present day practice of 6-7 LR may appear to be safe for wastewater users. However, the real virus population in wastewaters may be much more than what has been shown so far in the literature.

A particular concern in coronavirus outbreak is that many COVID-19 patients develop diarrhea (Y. Song et al., 2020), and the virus has been confirmed (Wu et al., 2020) in the stools of patients. In diarrheal patients, there are reports (Haas et al., 2014) that suggests viral particles could spike up to $10^{12}$ per gram of feces. In a recent study, Wu et al. (2020) reported more than $5 \log _{10}$ units of viral titers per liter of fecal materials collected from an urban wastewater treatment plant in Massachusetts. Another study by Zhang et al. (2020) suggested even higher, $10^{8}$ viral genomes per liter of fecal materials from COVID-19 patients. The highest so far has been reported by Wölfel et al. (2020) who observed a up to $10^{10}$ number of viral particles/L in a fecal sample of COVID-19 patient. This information can also be read in conjunction with the earlier studies of Drexier et al. (2011), Kirby et al. (2014) and Wen et al. (2019) who reported higher concentration of common enteric viruses in wastewater. Therefore, 6 to 7 average LR credits during wastewater disinfection can no longer serve as the standard practice, particularly at times when community transmission of a virus is at its peak. Since the novel coronavirus (SARS-CoV-2) is now perceived as an enteric pathogen, its survival in the sewage wastewater treatment process must now be investigated in greater details. It is also to be noted that higher average log reduction does not necessary mean a higher effective log reduction as shown by Schmidt et al. (2020). It is still unclear what range of effective removal of SARS-CoV-2 could be achieved through traditional disinfection processes. Special guidelines based on real-time analysis are therefore, required so that the irrigators using wastewaters do not get infected due to underestimated LR credit followed by the wastewater vendors. 
There are several factors that affect the concentration of viruses in wastewater. According to Gerba et al. (2017), virus load in wastewater varies on a temporal basis (season, time of day) and depends on how frequent and widespread an outbreak is. Temperature happens to be another important factor as concluded by La Rosa et al. (2020). Naturally, viral presence in wastewater recedes over time although asymptomatic infected individuals may continue to spread the virus. The concern is, new reports are emerging that states a significant number (AlTawfiq, 2020) of COVID-19 patients are asymptomatic (Table 1). Moreover, it is yet to understand whether patients who recover from COVID-19 develop a life-long or temporary immunity. Therefore, in post-COVID-19 times, even if the number of new cases nears zero, a close monitoring of wastewater quality is required. This would require not only identifying the SARS-CoV-2 virus in the wastewater collection, and distribution system but also quantifying the viral load through advanced molecular techniques. More importantly, updated guidelines need to be formulated with regards to log reduction credits (LRC) achieved during the disinfection processes. In connection to this, domestic greywater treatment guidelines also needs to be reviewed since it is often reused without any treatment posing greater risk to public health.

Table 1 Asymptomatic COVID-19 patients in different regions of the world.

\begin{tabular}{l|l|l}
\hline Location & Proportion & Reference \\
\hline \multirow{4}{*}{ China } & $>10 \%$ & (Day, 2020a; Han \& Yang, 2020; Hu et al., 2020) \\
\cline { 2 - 3 } & $18 \%-54 \%$ & (Nishiura et al., 2020) \\
\cline { 2 - 3 } & $14 \%-28 \%$ (children) & (Qiu et al., 2020; Sun et al., 2020) \\
\cline { 2 - 3 } & $22 \%$ & (H. Song et al., 2020) \\
\hline Germany & $22 \%$ & (Streeck et al., 2020) \\
\cline { 2 - 3 } & &
\end{tabular}




\begin{tabular}{|c|c|c|}
\hline Iceland & $50 \%$ & (Otmani, 2020; Renwick, 2020) \\
\hline India & $69 \%$ & (Dey, 2020) \\
\hline Iran & $18 \%$ & (Shakiba et al., 2020) \\
\hline Italy & $50 \%-75 \%$ & (Day, 2020b) \\
\hline \multirow[t]{3}{*}{ USA } & $25 \%$ & $(\mathrm{CDC}, 2020)$ \\
\hline & $57 \%$ & (Kimball et al., 2020) \\
\hline & 'most cases' & (Bendavid et al., 2020) \\
\hline
\end{tabular}

\section{Updating guidelines for greywater treatment and use}

The overwhelming evidence of the presence of viral particles in wastewaters makes it a possible agent of transmission (Hui \& Zumla, 2019) if not reclaimed properly. Compared to sewage wastewater, greywater is more likely to spread the coronavirus because of the lower treatment that it receives, and the sheer amount of it produced worldwide (Table 2). Also, greywater is often used in the cropping sector without any treatment at all (Raschid-Sally \& Jayakody, 2008) in many developing countries. For instance, in Bangladesh (Akhtar et al., 2015), India, Pakistan and Iran (Thebo et al., 2017) raw wastewater irrigation is a common practice in the peri-urban areas.

Table 2. Greywater production in different regions of the world.

\begin{tabular}{|l|l|l|}
\hline Regions & Greywater & References \\
& Production & \\
$($ L/capita/d & \\
& ay $)$ & \\
\hline
\end{tabular}




\begin{tabular}{|l|l|l|}
\hline Africa & $15-30$ & $\begin{array}{l}\text { (Alderlieste \& Langeveld, 2005; Bakare et al., 2016; } \\
\text { Katukiza et al., 2015; Olanrewaju \& Ilemobade, 2015) }\end{array}$ \\
\hline South and & $72-160$ & $\begin{array}{l}\text { (Busser et al., 2006; Mandal, et al., 2011; Oliver \& } \\
\text { Hossain, 2016) }\end{array}$ \\
\hline Australia & 120 & ANZS 1547:2000 \\
\hline Europe & $65-98$ & (Noutsopoulos et al., 2017; Ottoson \& Stenström, 2003) \\
\hline Middle East & $50-151$ & $\begin{array}{l}\text { (Al-Hamaiedeh \& Bino, 2010; Jamrah et al., 2008; Oron et } \\
\text { al., 2014; Underwood, 2012) }\end{array}$ \\
\hline USA & 123 & (L. M. Casanova et al., 2001; Hurlimann et al., 2016) \\
\end{tabular}

In the developed countries as well, for instance, the State of Victoria in Australia encourages its residents to recycle their own greywater for gardening (Department of Health and Human Services, 2020). It even puts the bath and shower water into the 'lower risk' category for irrigation. In the post COVID-19 times, such practice could potentially create a great public health concern. This is because, COVID-19 patients have been diagnosed with cough, vomiting (Gu et al., 2020) and their saliva contain higher number of SARS-CoV-2 viral particles (Holshue, et al., 2020). A recent study by Wyllie et al. (2020) has quantified the viral load in the saliva of COVID-19 hospital inpatients. It was shown (Fig. 1) that the patients' nasopharyngeal swabs, and the saliva contained more than $10^{10}$ viral copies $/ \mathrm{mL}$. If we take that $30 \mathrm{~mL}$ of water is required for a person to gargle once, and an average productive cough volume of around $1 \mathrm{~mL}$, the gargled greywater would contain at least $10^{11}$ infectious viral copies/L. A homestay COVID-19 patient's gargled water, in most common cases, usually go through the hand basins or shower outlets, and mixes with other sources of greywater. Fecal contamination of greywater (USEPA, 2012; WHO, 2006) is also a risk factor. Under these circumstances, 8 
untreated greywater is more likely to contain higher viral particles, and its use in surface irrigation cannot be marked as 'safe' or 'low risk' anymore in post COVID-19 times. In order to protect the irrigators and the public, further studies are therefore, needed regarding the risk of transmission of SARS-CoV-2 through greywater use in common irrigation practices.

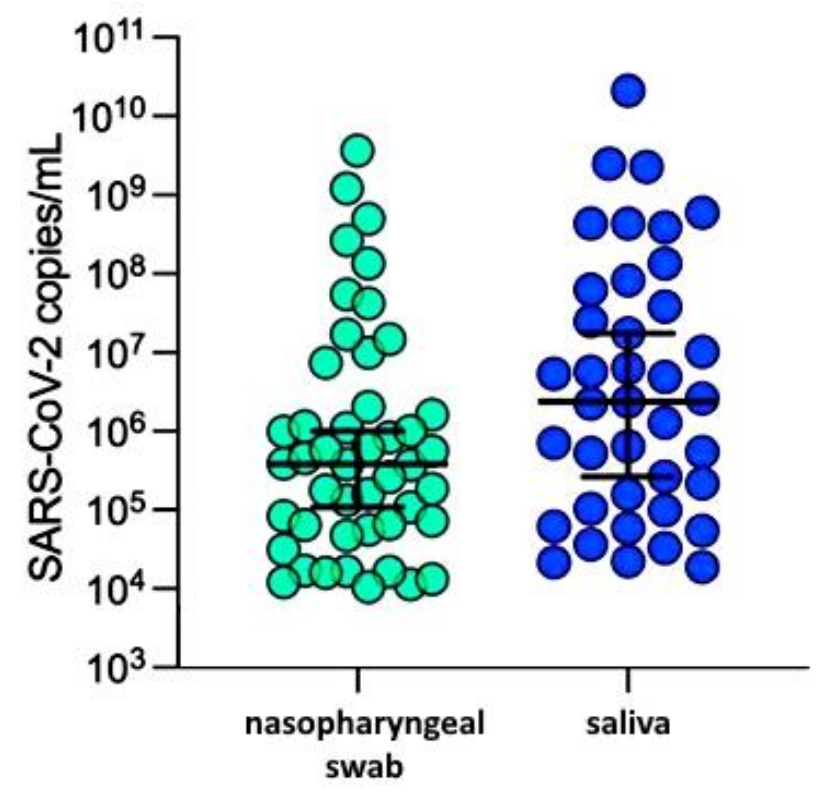

Figure 1. SARS-CoV-2 titers in the saliva and nasopharyngeal of hospital inpatients [after Wyllie et al. (2020) - permission obtained]

If this greywater containing unusually high amount of viral load is not treated and used for outdoor irrigation, there is an increased risk of infection for any healthy individual who may come in contact. This is because coronaviruses have been found to be 'exquisitely stable' (Florek et al., 2014) in aqueous environment, and could live up to 4 days (Gundy et al., 2009) in wastewater, and several weeks in tap water (L. Casanova et al., 2009). Nonetheless, if wastewater is used for irrigation in post-COVID-19 times, the choice of irrigation method could be critical (Pachepsky et al., 2011). In particular, irrigation methods (i.e., sprinkler) that generate 'aerosols' may be avoided. Aerosols are suspensions in the air/water interface and their size ranges between 0.001 to $100 \mu \mathrm{m}$ (Tang et al., 2006). Only 3\% of the water droplets (Molle et al., 2009) applied through micro-sprinklers are smaller than $100 \mu \mathrm{m}$, and being 
airborne may travel farther than the target area of application. This volume corresponds to a minimum application rate of $300 \mathrm{~mL} / \mathrm{m}^{2} / \mathrm{h}$ and is not accounted in usual irrigation efficiency studies. However, with regards to transmission of pathogens, such aerosol droplets are considered very important. An apprehension is that infectious aerosol from wastewater used in sprinkler droplets could potentially carry viral particles in far distances depending on the environmental factors (Pachepsky et al., 2011) in the field.

Information regarding pathogenic transport in irrigation systems are but few. A study by Molle \& Tomas (2016) in France has shed some light into this topic while experimenting with microsprinklers applying wastewater. In order to quantify small water droplets beyond the target zone, Molle \& Tomas (2016) mixed fluorescent dyes (traceable at $450 \mathrm{~nm}$ ) with wastewater. In order to collect airborne drifts which are more likely to create aerosol, 2-mm-diameter monofilaments were placed at different heights along with petri plates on the ground. The results showed that micro droplets were traceable $\left(4 \mathrm{mLh}^{-1} \mathrm{~m}^{-2}\right)$ even $50 \mathrm{~m}$ away from the sprinkler that has only $12.5 \mathrm{~m}$ irrigation range. The highest collections of these airborne droplets were recorded (up to $48 \mathrm{mLh}^{-1} \mathrm{~m}^{-2}$ ) within $20 \mathrm{~m}$ distance. It was also shown that higher wind speed tends to increase the volume of transport beyond the irrigation zone. An important observation was that the volume of droplets captured from air was more than that of the petri plates. This means micro particles are in the air has the potential to raise the aerosol content of areas far from the irrigation zone. It is very likely that such aerosols could be a potential source of transmission if the viral particles remain infectious due to lower LR credits achieved during wastewater treatment process. This apprehension is compounded by the fact that a widely accepted view behind SARS virus outbreak in Hong Kong (Cyranoski \& Abbott, 2003) was theorized to have been caused due to aerosols created from a leaked wastewater line.

This concern regarding SARS-CoV-2 transmission through greywater may be eliminated by introducing stricter wastewater treatment and reuse guidelines particularly during a potential 
outbreak like COVID-19. In extreme cases, where community transmission risk appears to be significantly high, a complete ban on the use of greywater irrigation may be implemented for a period until new cases of infection stops emerging. During these times, public safety measures may also be enforced in parks irrigated with secondary treated recycled water. This is because, treatments up to secondary disinfection are very poor (Ottoson, Hansen, Westrell, et al., 2006) at removing microorganisms, particularly viruses. A study by Ottoson, Hansen, Björlenius, et al. (2006) showed that secondary wastewater treatment plants' log reduction was less than 1.5 for common enteric viruses.

We understand that the present-day secondary disinfection protocols may well be ineffective in removing the novel coronavirus (SARS-CoV-2) from wastewaters. Although coronaviruses are thought to be unstable in oxidants (La Rosa et al., 2020), failure to quantify the viral titers accurately in greywater might lead to public health emergencies. Use of recycled water receiving secondary or less treatment must therefore, be limited in irrigation and other purposes during an outbreak. Considering the risk categories that we produced (Fig. 2), this situation could also be used to promote efficient microirrigation technologies such as subsurface drip irrigation (SDI) that protects the irrigators, and the fresh produces from direct contact with wastewater. These studies regarding recycled water irrigation brings the perspectives of the developed world. The developing countries, on the other hand, should be more concerned about this issue, since many of their surface water sources (i.e., rivers or canals) are known to be polluted (Thebo et al., 2017) with raw wastewater. We understand, in situations like COVID19 outbreak, stricter surface irrigation rules should be implemented in the developing countries in order to protect their marginal farming communities. 


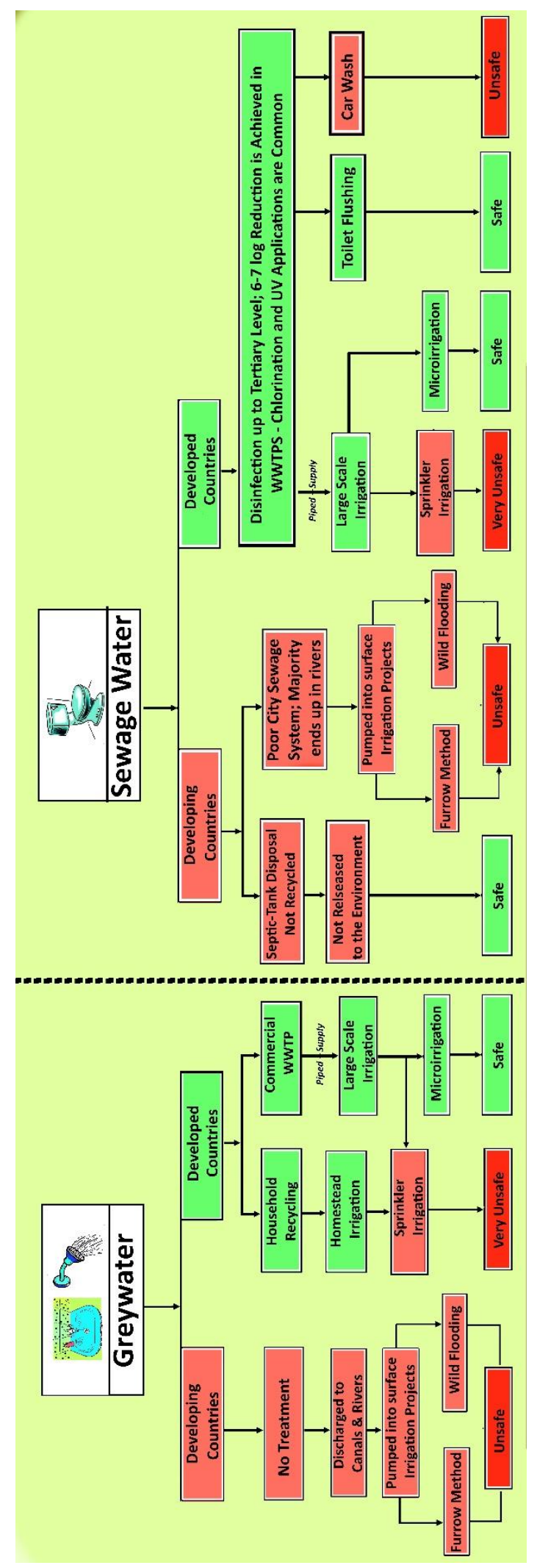

Figure 2 Wastewater sources, and their potential safety categories under different irrigation methods. 


\section{Conclusion}

Recycled wastewater is a sustainable alternative source of irrigation water in many countries. It is generally considered safe to use for homestead or commercial irrigation if the water is treated at appropriate levels. With regards to microbial disinfection of wastewater, typical 6-7 $\log _{10}$ reduction credit has been is followed in the industry. Recent research endeavors has however, convincingly showed that viral particles in wastewater can exceed this threshold. The studies regarding SARS-CoV-2 virus responsible for COVID-19 pandemic has reported that the viral titer in the sewage effluents could reach up to $10 \log _{10}$ units. In household greywater generated from COVID-19 patients, the viral titer has also been documented to reach up to 10 $\log _{10}$ units/L. This means untreated greywater irrigation practice could potentially help transmit the novel coronavirus which is now perceived as an enteric pathogen. Therefore, the wastewater industry should be concerned about revising the effective log reduction (LR) credits for viruses from wastewaters particularly during a pandemic. The data also suggests that the choice of irrigation method could be critical in limiting the spread of viral particles from wastewater. Methods that create aerosols (i.e., sprinklers) may be advised to operate with caution in order protect the public working or living in the vicinity of 50 meters. We strongly feel that even if the pandemic recedes, water treatment plants should strictly, and regularly monitor their products since the novel corona virus has been shown to survive in water for days to weeks. Meanwhile, authorities may reconsider their advice regarding irrigation with locally reclaimed greywater. This situation also calls for renewed efforts to promote microirrigation technology that can safely irrigate the soil without letting farmers, and fresh produces coming into direct contact with the wastewater. 


\section{References}

Akhtar, P., Ahmed, Y., Islam, F., Alam, K., Mary, M., Islam, M. Z., Bhuiyan, M. M. H., \& Yaakob, Z. (2015). Efficiency of Effluent Treatment Plants and Threat to Human Health and Aquatic Environment in Bangladesh. Asian Journal of Chemistry, 28, 6068. https://doi.org/10.14233/ajchem.2016.19230

Alderlieste, M. C., \& Langeveld, J. G. (2005). Wastewater planning in Djenne, Mali. A pilot project for the local infiltration of domestic wastewater. Water Science and Technology, 51(2), 57-64.

Al-Hamaiedeh, H., \& Bino, M. (2010). Effect of treated grey water reuse in irrigation on soil and plants. Desalination, 256, 115-119. https://doi.org/10.1016/j.desal.2010.02.004

Al-Tawfiq, J. A. (2020). Asymptomatic coronavirus infection: MERS-CoV and SARS-CoV-2 (COVID-19). Travel Medicine and Infectious Disease, 101608. https://doi.org/10.1016/j.tmaid.2020.101608

Asano, T., Franklin, B. H., Leverenz, L., Tsuchihashi, R., \& Tchobanoglous, G. (2007). Water Reuse: Issues, Technologies, and Applications. (1st ed.). McGraw-Hill, New York. http://www.accessengineeringlibrary.com/content/book/9780071459273

Bakare, B. F., Mtsweni, Sphesihle, \& Rathilal, S. (2016). A pilot study into public attitudes and perceptions towards greywater reuse in a low cost housing development in Durban, South Africa. Journal of Water Reuse and Desalination, 6(2), 345-354. https://doi.org/10.2166/wrd.2015.076

Bendavid, E., Mulaney, B., Sood, N., Shah, S., Ling, E., Bromley-Dulfano, R., Lai, C., Weissberg, Z., Saavedra-Walker, R., Tedrow, J., Tversky, D., Bogan, A., Kupiec, T., Eichner, D., Gupta, R., Ioannidis, J., \& Bhattacharya, J. (2020). COVID-19 Antibody Seroprevalence in Santa Clara County, California. Epidemiology, medRxiv-The Preprint Server for Health Sciences. https://doi.org/10.1101/2020.04.14.20062463

Bosch, A., Gkogka, E., Guyader, F. S. [Le, Loisy-Hamon, F., Lee, A., Lieshout, L. [van, Marthi, B., Myrmel, M., Sansom, A., Schultz, A. C., Winkler, A., Zuber, S., \& Phister, T. (2018). Foodborne viruses: Detection, risk assessment, and control options in food processing. International Journal of Food Microbiology, 285, 110-128. https://doi.org/10.1016/j.ijfoodmicro.2018.06.001 
Busser, S., Pham, T. N., \& Nguyen, V. A. (2006). Characterisitcs and quantities of domestic wastewater in urban and peri-urban households in Hanoi (Annual Report FY 2006; The Core Program University Program between Japan Society for the Promotion of Science and Vietnam Academy of Science and Technology, pp. 395-397). Japan Society for the Promotion of Science and Vietnam Academy of Sciencec and Technology. http://ir.library.osaka-u.ac. jp/dspace/bitstream/11094/13204/1/arfyjsps2006_395.pdf

Casanova, L. M., Gerba, C. P., \& Karpiscak, M. (2001). Chemical and microbial characterization of household greywater. Journal of Environmental Science and Health - Part A Toxic/Hazardous Substances and Environmental Engineering, 34, 395-401.

Casanova, L., Rutala, W. A., Weber, D. J., \& Sobsey, M. D. (2009). Survival of surrogate coronaviruses in water. Water Research, 43(7), 1893-1898. https://doi.org/10.1016/j.watres.2009.02.002

CDC. (2013). Updated information on the epidemiology of Middle East respiratory syndrome coronavirus (MERS-CoV) infection and guidance for the public, clinicians, and public health authorities, 2012-2013. Microbial Mortality Weekly Report, Centers for Disease Control and Prevention, 62(793-796.).

CDC. (2020). Coronavirus Disease 2019 (COVID-19). [US Government Website]. Centers for Disease Control and Prevention. https://www.cdc.gov/coronavirus/2019ncov/hcp/clinical-guidance-management-patients.html\#Asymptomatic

Cyranoski, D., \& Abbott, A. (2003). Apartment complex holds clues to pandemic potential of SARS. Nature, 423(1038).

Day, M. (2020a). Covid-19: Identifying and isolating asymptomatic people helped eliminate virus in Italian village. $B M J, \mathrm{~m} 1165$. https://doi.org/10.1136/bmj.m1165

Day, M. (2020b). Covid-19: Four fifths of cases are asymptomatic, China figures indicate. $B M J$, m1375. https://doi.org/10.1136/bmj.m1375

Department of Health and Human Services. (2020). Greywater-Recycling water at home [Victorian State Government Website, Australia]. Better Health Channel. www.betterhealth.vic.gov.au/health/HealthyLiving/Greywater-recycling-water-athome 
Dey, S. (2020, April 22). COVID 19 India: 69\% of cases found positive were asymptomatic: ICMR | India News-Times of India. Times of India. https://timesofindia.indiatimes.com/india/69-of-cases-found-positive-wereasymptomatic-icmr/articleshow/75282825.cms

Drexier, J. F., Baumgarte, S., de Souza Luna, L. K., Eschbach-Bludau, M., Lukashev, A. N., \& Drosten, C. (2011). Aichi virus shedding in high concentrations in patients with acute diarrhea. Emerging Infectous Diseases, 17(8), 1544-1547. https://doi.org/10.3201/eid1708.101556

Florek, D., Burmistrz, M., Potempa, J., \& Pyrc, K. (2014). Stability of infectious human coronavirus NL63. Journal of Virological Methods, 205, 87-90. https://doi.org/10.1016/j.jviromet.2014.04.001

Gerba, C. P., Betancourt, W. Q., \& Kitajima, M. (2017). How much reduction of virus is needed for recycled water: A continuous changing need for assessment? Water Research, 108, 25-31. https://doi.org/10.1016/j.watres.2016.11.020

Gu, J., Han, B., \& Wang, J. (2020). COVID-19: Gastrointestinal manifestations and potential fecal-oral transmission. Gastroenterology. https://doi.org/10.1053/j.gastro.2020.02.054

Gundy, P. M., Gerba, C. P., \& Pepper, I. L. (2009). Survival of Coronaviruses in Water and Wastewater. Food and Environmental Virology, 1, 10-14. https://doi.org/10.1007/s12560-008-9001-6

Haas, C. H., Rose, J. B., \& Gerba, C. P. (2014). Microbial agents and transmission. In C. H. Haas (Ed.), Quantitative Microbial Risk Assessment. (pp. 15-62). John Wiley \& Sons, Inc.

Han, Y., \& Yang, H. (2020). The transmission and diagnosis of 2019 novel coronavirus infection disease (COVID-19): A Chinese perspective. Journal of Medical Virology, 92(6), 639-644. https://doi.org/10.1002/jmv.25749

Holshue, M. L., DeBolt, C., ... Lindquist, S. (2020). First Case of 2019 Novel Coronavirus in the United States. New England Journal of Medicine. https://doi.org/10.1056/NEJMoa2001191

Hu, Z., Song, C., Xu, C., Jin, G., Chen, Y., Xu, X., Ma, H., Chen, W., Lin, Y., Zheng, Y., Wang, J., Hu, Z., Yi, Y., \& Shen, H. (2020). Clinical characteristics of 24 asymptomatic 
infections with COVID-19 screened among close contacts in Nanjing, China. Science China Life Sciences, 63(5), 706-711. https://doi.org/10.1007/s11427-020-1661-4

Hui, D. S. C., \& Zumla, A. (2019). Severe acute respiratory syndrome: Historical, epidemiologic, and clinical features. Infectious Disease Clinics of North America, 33, 869-89. https://doi.org/10.1016/j.idc.2019.07.001

Hurlimann, A., Hurlimann, A., \& Dolnicar, S. (2016). Public acceptance and perceptions of alternative water sources: A comparative study in nine locations. International Journal of Water Resources Development, 32(4), 650-673.

Jamrah, A., Al-Futaisi, A., Prathapar, S., \& Harrasi, A. A. (2008). Evaluating greywater reuse potential for sustainable water resources management in Oman. Environmental Monitoring and Assessment, 137, 315-327. https://doi.org/10.1007 /s10661-007-97672.

Katukiza, A. Y., Ronteltap, M., Niwagaba, C. B., Kansiime, F., \& Lens, P. N. L. (2015). Grey water characterisation and pollutant loads in an urban slum. International Journal of Environmental Science and Technology, 12, 423-436. https://doi.org/10.1007/s13762013-0451-5

Kimball, A., Hatfield, K. M., Arons, M., James, A., Taylor, J., Spicer, K., Bardossy, A. C., Oakley, L. P., Tanwar, S., Chisty, Z., Bell, J. M., Methner, M., Harney, J., Jacobs, J. R., Carlson, C. M., McLaughlin, H. P., Stone, N., Clark, S., Brostrom-Smith, C., ... CDC COVID-19 Investigation Team. (2020). Asymptomatic and Presymptomatic SARS-CoV-2 Infections in Residents of a Long-Term Care Skilled Nursing FacilityKing County, Washington, March 2020. MMWR. Morbidity and Mortality Weekly Report, 69(13), 377-381. https://doi.org/10.15585/mmwr.mm6913e1

Kirby, A. E., Shi, J., Montes, J., Lichtenstein, M., \& Moe, C. L. (2014). Disease course and viral shedding in experimental Norwalk virus and Snow Mountain virus infection. Journal of Medical Virology, 86(12), 2055-2064. http://refhub.elsevier.com/S01604120(16)30081-2/rf0120

La Rosa, G., Bonadonna, L., Lucentini, L., Kenmoe, S., \& Suffredini, E. (2020). Coronavirus in water environments: Occurrence, persistence and concentration methods - A scoping review. Water Research, 179, 115899. https://doi.org/10.1016/j.watres.2020.115899 
Lodder, W., \& Husman, A. M. de R. (2020). SARS-CoV-2 in wastewater: Potential health risk, but also data source. The Lancet Gastroenterology \& Hepatology, 1253(20), 30087. https://doi.org/10.1016/S2468-1253(20)30087-X

Mäde, D., Trübner, K., Neubert, E., Höhne, M., \& Johne, R. (2013). Detection and typing of norovirus from frozen strawberries involved in a large-scale gastroenteritis outbreak in Germany. Food and Environmental Virology, 5, 162-168. https://doi.org/10.1007/s12560-013-9118-0

Mallapaty, S. (2020). How sewage could reveal true scale of coronavirus outbreak. Nature, $580,176$.

Mandal, D., Labhasetwar, P., Dhone, S., Dubey, A. S., Shinde, G., \& Wate, S. (2011). Water conservation due to greywater treatment and reuse in urban setting with specific context to developing countries. Resources Conservation and Recycling, 55, 356-361. https://doi.org/10.1016/j. resconrec.2010.11.001

Manocha, S., K.R. Walley, \& Russell, J. A. (2003). Severe acute respiratory distress syndrome (SARS): A critical care perspective. Critical Care Medicine, 31, 2684-2692.

Medema, G., Heijnen, L., Elsinga, G., Italiaander, R., \& Medema, G. (2020). Presence of SARS-Coronavirus-2 in sewage. MedRxiv - The Preprint Server for Health Sciences. https://doi.org/10.1101/2020.03.29.20045880

Molle, B., Huet, L., Tomas, S., Granier, J., Dimaiolo, P., \& Rosa, C. (2009). Characterization of drift and evaporation risks of a series of sprinklers: Application in defining the limits of sprinkling with treated waste in reuse purpose [Cemagref Open Archive]. CemOA: IRSTEA. https://irsteadoc.irstea.fr/oa/PUB00031625-caracterisation-risque-deriveevaporation-une-gamm.html

Molle, B., \& Tomas, S. (2016). Experimental Approach to Assessing Aerosol Dispersion of Treated Wastewater Distributed via Sprinkler Irrigation. Journal of Irrigation and Drainage Engineering, 04016031, 1-8. https://doi.org/10.1061/(ASCE)IR.19434774.0001039

Nishiura, H., Kobayashi, T., Miyama, T., Suzuki, A., Jung, S., Hayashi, K., Kinoshita, R., Yang, Y., Yuan, B., Akhmetzhanov, A. R., \& Linton, N. M. (2020). Estimation of the asymptomatic ratio of novel coronavirus infections (COVID-19). International Journal of Infectious Diseases, 94, 154-155. https://doi.org/10.1016/j.ijid.2020.03.020 
Noutsopoulos, C., Andreadakis, A., Kouris, N., Charchousi, D., Mendrinou, P., Galani, A., Mantziaras, I., \& Koumaki, E. (2017). Greywater characterization and loadings Physicochemical treatment to promote onsite reuse. Journal of Environmental Management., 216. https://doi.org/10.1016/j.jenvman.2017.05.094.

Olanrewaju, O., \& Ilemobade, A. (2015). Greywater Reuse Review and Framework for Assessing Greywater Treatment Technologies for Toilet Flushing. Advances in Research. 5(1-25). https://doi.org/10.9734/AIR/2015/19117

Oliver, M., \& Hossain, S. (2016). Effect of greywater irrigation on wheat and mung-bean production in clayey-loam soil. Journal of Bioscience and Agriculture Research, 7(2), 659-668. https://doi.org/10.18801/jbar.070216.78

Oron, G., Adel, M., Agmon, V., Friedler, E., Halperin, R., Leshem, E., \& Weinberg, D. (2014). Greywater use in Israel and worldwide: Standards and prospects. Water Research, 58, 92-101. https://doi.org/10.1016/j.watres.2014.03.032

Otmani, M. (2020). COVID-19: First results of the voluntary screening in Iceland. Nordic Life Science - the Leading Nordic Life Science News Service. https://nordiclifescience.org/covid-19-first-results-of-the-voluntary-screening-iniceland/

Ottoson, J., Hansen, A., Björlenius, B., Norder, H., \& Stenström, T. A. (2006). Removal of viruses, parasitic protozoa and microbial indicators in conventional and membrane processes in a wastewater pilot plant. Water Research, 40(7), 1449-1457. https://doi.org/10.1016/j.watres.2006.01.039

Ottoson, J., Hansen, A., Westrell, T., Johansen, K., Norder, H., \& Stenström, T. A. (2006). Removal of Noro- and Enteroviruses, Giardia Cysts, Cryptosporidium Oocysts, and Fecal Indicators at Four Secondary Wastewater Treatment Plants in Sweden. Water Environment Research, 78(8), 828-834. https://doi.org/10.2175/106143006X101719

Ottoson, J., \& Stenström, T. A. (2003). Faecal contamination of greywater and associated microbial risks. Water Research, 37(3), 645-655. https://doi.org/10.1016/S00431354(02)00352-4

Pachepsky, Y., Shelton, D. R., McLain, J. E. T., Patel, J., \& Mandrell, R. E. (2011). Irrigation as a source of pathogenic microorganisms in produce: A review. In Advances in 
Agronomy (2nd ed., Vol. 113, pp. 73-138). https://doi.org/10.1016/B978-0-12-3864734.00007-5

Peiris, J. S., Lai, S.T., Poon, L.L., Guan, Y., Yam, L.Y., Lim, W., Nicholls, J., Yee, W.K., Yan,W.W., Cheung, M.T., Cheng, V.C., Chan, K.H., Tsang, D.N., Yung, R.W., Ng, T.K., Yuen, K.Y., \& SARS study group. (2003). Coronavirus as a possible cause of severeacute respiratory syndrome. Lancet, 361, 1319-1325.

Qiu, H., Wu, J., Hong, L., Luo, Y., Song, Q., \& Chen, D. (2020). Clinical and epidemiological features of 36 children with coronavirus disease 2019 (COVID-19) in Zhejiang, China: An observational cohort study. The Lancet Infectious Diseases, S1473309920301985. https://doi.org/10.1016/S1473-3099(20)30198-5

Queensland Water Supply Regulator. (2008). Water qualilty guidelines for recycled water schemes. Government of Queensland. www.dews.qld.gov.au

Raschid-Sally, L., \& Jayakody, P. (2008). Drivers and characteristics of wastewater agriculture in developing countries: Results from a global assessment (International Water Management Institue IWMI Research Report 127).

Renwick, D. (2020). Have I already had coronavirus? How would I know and what should I do? The Guardian. http://www.theguardian.com/us-news/2020/apr/05/have-i-alreadyhad-coronavirus-how-would-i-know

Sarvikivi, E., Roivainen, M., Maunula, L., Niskanen, T., Korhonen, T., Lappalainen, M., \& Kuusi, M. (2012). Multiple norovirus outbreaks linked to imported frozen raspberries. Epidemiologyand Infection, 260-267. https://doi.org/10.1017/S0950268811000379

Schmidt, P. J., Anderson, W. B., \& Emelko, M. B. (2020). Describing water treatment process performance: Why average log-reduction can be a misleading statistic. Water Research, 176, 115702. https://doi.org/10.1016/j.watres.2020.115702

Shakiba, M., Hashemi Nazari, S. S., Mehrabian, F., Rezvani, S. M., Ghasempour, Z., \& Heidarzadeh, A. (2020). Seroprevalence of COVID-19 virus infection in Guilan province, Iran. Infectious Diseases (except HIV/AIDS), medRxiv-The Preprint Server for Health Sciences. https://doi.org/10.1101/2020.04.26.20079244

Song, H., Xiao, J., Qiu, J., Yin, J., Yang, H., Shi, R., \& Zhang, W. (2020). A considerable proportion of individuals with asymptomatic SARS-CoV-2 infection in Tibetan 
population. Infectious Diseases (except HIV/AIDS), medRxiv-The Preprint Server for Health Sciences. https://doi.org/10.1101/2020.03.27.20043836

Song, Y., Liu, P., Shi, X. L., Chu, Y. L., Zhang, J., Xia, J., Gao, X. Z., Qu, T., \& Wang, M. Y. (2020). SARS-CoV-2 induced diarrhoea as onset symptom in patient with COVID-19. Gut Epub, O(1-2), gutjnl-2020-320891. https://doi.org/10.1136/gutjnl-2020-320891

Streeck, H., Schulte, B., Kuemmerer, B., Richter, E., Hoeller, T., Fuhrmann, C., Bartok, E., Dolscheid, R., Berger, M., Wessendorf, L., Eschbach-Bludau, M., Kellings, A., Schwaiger, A., Coenen, M., Hoffmann, P., Noethen, M., Eis-Huebinger, A.-M., Exner, M., Schmithausen, R., ... Kuemmerer, B. (2020). Infection fatality rate of SARS-CoV2 infection in a German community with a super-spreading event. Infectious Diseases (except HIV/AIDS). https://doi.org/10.1101/2020.05.04.20090076

Sun, W. W., Ling, F., Pan, J. R., Cai, J., Miao, Z. P., Liu, S. L., Cheng, W., \& Chen, E. F. (2020). [Epidemiological characteristics of 2019 novel coronavirus family clustering in Zhejiang Province]. Zhonghua Yu Fang Yi Xue Za Zhi [Chinese Journal of Preventive Medicine], 54(0), E027. https://doi.org/10.3760/cma.j.cn112150-20200227-00199

Tang, J. W., Li, Y., Eames, I., \& Chan, P. K. (2006). Factors involved in the aerosol transmission of infection and control of ventilation in healthcare premises. Journal of Hosptital Infections, 64, 100-114.

Terio, V., Bottaro, M., Di Pinto, A., Catella, C., Chironna, M., \& Bozzo, G. (2015). Outbreak of hepatitis A in Italy associated with frozen redcurrants imported from Poland: A case study. Food and Environmental Virology, 7, 305-308. https://doi.org/10.1007/s12560015-9199-z

Thebo, A. L., Drechsel, P., Lambin, E., \& Nelson, K. (2017). A global, spatially-explicit assessment of irrigated croplands influenced by urban wastewater flows. Environmental Research Letters, 12(7), 20. https://doi.org/10.1088/1748-9326/aa75d1

Underwood, M. (2012). Going grey can help ease UAE's water woes. The National. https://www.thenational.ae/uae/environment/going-grey-can-help-ease-uae-s-waterwoes- 1.388228

USEPA. (1990). Guidance manual for compliance with the filtration and disinfection requirements for public water systems using surface water sources. Science and Technology Branch, Criteria and Standards Division, Office of Drinking Water, United 
States Environmental Protection Agency. https://www.epa.gov/sites/prodution/files/2015-

10/documents/Guidance_manual_for_compliance_with_the_filtration_and_disinfectio n_requirements.pdf

USEPA. (2012). Guidelines for Water Reuse. United States Environmental Protection Agency. http://nepis.epa.gov/Adobe/PDF/P100FS7K.pdf

USEPA. (2016). Surface Water Treatment Rules [United States Environmental Protection Agency]. Drinking Water Requirements for States and Public Water Systems. https://www.epa.gov/dwreginfo/surface-water-treatment-rules

Wang, X., Li, J., Guo, T., Zhen, B., Kong, Q., Yi, B., Li, Z., Song, N., Jin, M., Xiao, W., Zhu, X., Gu, C., Yin, J., Wang, G., Qiu, Y., Wu, H., Chao, F., \& Li, J. (2005). Concentration and detection of SARS coronavirus in sewage from Xiao Tang Shan Hospital and the 309th Hospital. Journal of Virological Methods, 128(2005), 156-161. https://doi.org/10.1016/j.jviromet.2005.03.022

Wen, X., Zheng, H., Yuan, F., Zhu, H., Kuang, D., Shen, Z., \& Lu, Y. (2019). Comparative Study of Two Methods of Enteric Virus Detection and Enteric Virus Relationship with Bacterial Indicator in Poyang Lake, Jiangxi, China. International Journal of Environmental Research and Public Health, 16(3384). https://doi.org/10.3390/ijerph16183384

WHO. (2006). WHO Guidelines for the Safe Use of Wastewater, Excreta and GreywaterVolume 4 (Excreta and Greywater Use in Agriculture). World Health Organization. http://www.susana.org/en/resources/library/ details/1004

WHO. (2020, January 31). 2019-nCoV outbreak is an emergency of international concern. World Health Organization. http://www.euro.who.int/en/health-topics/healthemergencies/international-health-regulations/news/news/2020/2/2019-ncov-outbreakis-an-emergency-of-international-concern

Wölfel, R., Corman, V. M., Guggemos, W., Seilmaier, M., Zange, S., Müller, M. A., Niemeyer, D., Jones, T. C., Vollmar, P., Rothe, C., Hoelscher, M., Bleicker, T., Brünink, S., Schneider, J., Ehmann, R., Zwirglmaier, K., Drosten, C., \& Wendtner, C. (2020). Virological assessment of hospitalized patients with COVID-2019. Nature. https://doi.org/10.1038/s41586-020-2196-X 
Wu, F. Q., Xiao, A., Zhang, J. B., Gu, X. Q., Lee, W., Kauffman, K. H., Ghaeli, N., Endo, N., Duvallet, C., Moniz, K., Erickson, T. B., Chai, P. R., Thompson, J., \& Alm, E. J. (2020). SARS-CoV-2 titers in wastewater are higher than expected from clinically confirmed cases. MedRxiv - The Preprint Server for Health Sciences, Preprint. https://doi.org/10.1101/2020.04.05.20051540

Wu, Y., Guo, C., Tang, L., Hong, Z., Zhou, J., Dong, X., Yin, H., Xiao, Q., Tang, Y., Qu, X., Kuang, L., Fang, X., Mishra, N., Lu, J., Shan, H., Jiang, G., \& Huang, X. (2020). Prolonged presence of SARS-CoV-2 viral RNA in faecal samples. The Lancet Gastroenterology \& Hepatology, 0. https://doi.org/10.1016/S2468-1253(20)30083-2

Wyllie, A. L., Fournier, J., Casanovas-Massana, A., Campbell, M., Tokuyama, M., Vijayakumar, P., Geng, B., Muenker, M. C., Moore, A. J., Vogels, C. B. F., Petrone, M. E., Ott, I. M., Lu, P., Lu-Culligan, A., Klein, J., Venkataraman, A., Earnest, R., Simonov, M., Datta, R., ... Ko, A. I. (2020). Saliva is more sensitive for SARS-CoV-2 detection in COVID-19 patients than nasopharyngeal swabs [Preprint]. Infectious Diseases (except HIV/AIDS). https://doi.org/10.1101/2020.04.16.20067835

Zaki, A., van Boheemen, S., Bestebroer, T.M., Osterhaus, A.D., \& Fouchier, R.A. (2012). Isolation of a novel coronavirus from a man with pneumonia in Saudi Arabia. New England Journal of Medicine, 367, 1814-1820.

Zhang, N., Gong, Y., Meng, F., Bi, Y., Yang, P., \& Wang, F. (2020). Virus shedding patterns in nasopharyngeal and fecal specimens of COVID-19 patients. Infectious Diseases (except HIV/AIDS), medRxiv-The Preprint Server for Health Sciences. https://doi.org/10.1101/2020.03.28.20043059 